since the latter pass into the former. Hence, if a pair of overthrusts dip towards one another, it is highly probable that the area they enclose was primarily a syncline, or, on the other hand, if they dip away from one another, an anticline. Thus, from the direction of the two great series of thrust-planes which form the north-western and south-eastern boundaries of the Grampians it seems probable that that region began its tectonic history as a syncline, while the central lowlands, on the other hand, would seem to have been a corresponding anticline.

It will be observed that the Central Lowlands now form a broad syncline. But that is just what should be expected. From a consideration of what has already been said it should be clear that the original folds tend to become virtually reversed, the axes of the synclines raised, and the summits of the anticlines depressed.

No doubt, from the premises that the form of a minor fold is influenced by the side-shift of superposed beds caused by the formation of a larger fold in which it is contained, many more interesting deductions might be drawn, but enough has, I think, been said to illustrate the nature and general effect of that influence. That the relation here stated is the only cause of the deformation of minor folds I would not wish in any way to suggest. The series of strains and stresses set up in the terrestrial crust must be more complex than we can ever hope to completely disentangle. But I do maintain that we have here a distinct set of effects which can be separately recognised and traced to a definite cause. That other influences must give rise to irregularities is inevitable. Yet I think an appeal to the rocks shows that there is still, in many cases at least, a distinctly recognisable residue of effects which may be traced to this one cause, by the observation and consideration of which much help may be derived in the elucidation of the tectonic history of complex districts.

\title{
MOTICES OF MEMOIRS.
}

\section{I.-Index Generdil et Speciertum Amimalidu. ${ }^{1}$}

THE indexing of the literature for the second portion of this Index 1 (1801-1850) has steadily progressed. Among the works included are:-Archiv für Bergbuu, etc., 43 vols.; Archiv für die gesammte Naturlehre, 27 vols.; Archiv für Naturgeschichte, 16 vols.; Athenæum, 23 vols.; Basel, Naturforschende Gesellschaft, 8 vols.; Batavia, Batav. Genootsch., 16 rols.; Beiträge zur Petrefactenkunde (Muensters); Berlin, Gesellschaft naturforschende Freunde; Berlin, Bericht und

1 Report of the Committee, consisting of Dr. Henry Woodward (Chairman), Dr. F. A. Bather (Secretary), Dr. P. L. Sclater, Rev. T. R. R. Stebbing, Dr. W. E. Hoyle, Hon. Walter Rothschild, and Lord Walsingham. By C. Davies Sherborn, F.G.S., F.Z.S. Read before Section D (Zoology), British Association, Leicester, 1907. 
Abhandlung k. pr. Akad. Wiss., 50 vols.; as also the writings of Audouin, Audebert, Audubon, Audinet, and Bechstein, a list which might be considerably extended.

The accumulated results of three years recording have now all been arranged and sorted under their respective genera, and, therefore, one set of entries is now available for reference by monographers so far as recording has proceeded. The duplicate set of entries has been partially arranged and further accommodation has been provided by the kindness of Dr. Smith Woodward in the Geological Department of the British Museum (Natural History), which has greatly relieved the pressure arising from the steady growth of material.

\section{II.-Investigation of the Pre-Devonian Beds of the MIendipg. ${ }^{1}$}

THE principal objects which the Committee had in view were two 1 in number-(1) To obtain a further series of fossils from the newly discovered Silurian beds of the area. (2) To investigate the distribution in the field of a peculiar coarse ashy conglomerate, and to ascertain its relations to the other deposits of the neighbourhood. With these ends in view a series of seven trenches was dug, and the information obtained from them was incorporated in a paper by the Secretary. ${ }^{2}$

The most easterly of these trenches was dug in a field about 300 yards S.S.W. of Tadhill Farm. It was carried to a depth of about six feet, and after passing through some 18 inches of surface material, entered a deposit consisting mainly of very fine yellow and brown ash, with subordinate bands of coarse ash. Many of the bands were crowded with fossils, which were identified by Mr. F. R. C. Reed. ${ }^{3}$ The series of fossils, though undoubtedly Silurian, and, in Mr. Reed's opinion, probably of Upper Llandovery age, was insufficient to determine the point with certainty.

A second trench dug at a point about 100 yards to the north of that in the fossiliferous tuff proved to be in trap (pyroxene andesite).

The remaining five trenches were all dug in the neighbourhood of the rifle butts on Beacon Hill (about a quarter of a mile to the north of Beacon Farm), where the coarse ashy conglomerate was originally exposed in a target pit. Four trenches dug at different points in the neighbourhood of the rifle butts showed that the coarse ashy conglomerate here probably occupies the whole area between the northern and southern outcrops of the Old Red Sandstone. A fifth trench was opened on the slope of the hill to the north of the rifle butts, but after passing through nine feet of Old Red Sandstone this trench was abandoned.

1 Report of the Committee, consisting of Mr. H. B. Woodward (Chairman), Professor C. Lloyd Morgan, the Rev. H. H. Winwood, and Professor S. H. Reynolds (Secretary). (Drawn up by the Secretary.) Read before Section $\mathbf{C}$ (Geology), British Association, Leicester, 1907.

2 Published in the Quart. Journ. Geol. Soc., vol. lxiii (1907), pp. 217-238.

3 See list, op. cit., pp. 226-227. 
III.-Desert Conditrons and the Origin of the British Trias. By J. Lomas, A.R.C.S., F.G.S.

$\mathrm{T} T$ is now generally conceded that the Triassic rocks of our Islands 1 are not of marine origin, but true continental deposits, and the view has of late gathered strength that the climate was arid when they were laid down. We can only hope to reach a safe conclusion by a critical examination of existing deserts. Let us confine ourselves to a consideration of the activities now at work in some typical sandy deserts, such as we suppose to have existed in Triassic times.

\section{SANDY DESERTS.}

Rainfall.-As a rule sandy deserts are characterised by a low rainfall, and their distribution is in general either on the leeward sides of mountain ranges or in valleys and plateaux between such ranges. In Northern Egypt the precipitation ranges from 0.27 inch at Cairo, to $1 \cdot 1$ in. at Suez, $2 \cdot 1$ in. at Ismailia, 3.4 in. at Port Said, and $8 \cdot 1$ in. at Alexandria. In South California and West Arizona certain regions have a mean annual rainfall of less than 2 inches. In the Karoo the precipitation varies from 8.65 inches at Steotleville to 18.76 in. at Graaff-Reinet (Buchan). In the Kalahari desert from $3 \cdot 79$ in. at Pella to $41 \cdot 10$ in. at Pilgrims Rest. On the west coast of Africa from $2 \cdot 11$ in. at Port Nolloth to $8 \cdot 37$ in. at Clan William.

Examples need not be multiplied; those quoted are sufficient to show that the amount is generally small and varies very considerably in different places. An equally important consideration is the time during which rain falls. If the precipitation is confined to one season and for the rest of the year there is little or no rain, desert conditions may exist, although the annual rainfall is comparatively large. During the wet season the ground may be well watered, and streams of torrential size flow over the country, but the water is soon lost by percolation or evaporation and none is stored up to water the land in time of drought.

Vegetation is either very scant or absent, and the lack of regetable mould diminishes the power of the soil to retain moisture. Professor N. S. Shaler (U.S. Geol. Surv. 12th Report) points out too that the absence of regetable mould commonly causes the soil to present a dense baked surface which sheds rain like a roof.

Streams of Desert Regions.- In South Africa during the dry season we often come across deep watercourses excavated during the time of the seasonal rains but now perfectly dry. Their beds are covered with well-rounded boulders of such a size as to indicate that torrents must have flowed down the courses in order to move them. Towards the mountains the banks become steeper and loftier, while in the direction of the plain the valley merges into the general outlines of the veldt, and at the junction it is marked by a spread of pebbles. In the Libyan and Algerian deserts similar watercourses are found in the neighbourhood of their enclosing mountains. They are liable

1 Proc. Liverpool Geol. Soc., vol. x, pt. 3, 1907, pp. 172-180; slightly abridged. 
to floods of so sudden appearance and of such torrential violence that people engaged in gathering firewood, brought down by former floods, are sometimes overtaken and have no chance of escape. At one time the bed may be perfectly dry and a moment later it is filled with a rapid stream hundreds of feet wide. In India these sudden floods are sometimes miles in width; they have no defined channel, but flow like a sheet over the land.

It is worth while at this stage to picture what kinds of deposits are being formed under the conditions just described. While the main portion will be composed of sand there will be included at various horizons patches of gravel, lenticular in shape and of limited extent. I have seen sections through such deposits in a dry donga near Tintas Kopje in the Vryheid district, and again in railway cuttings when traversing the Eastern desert of Egypt between Ismailia and Cairo. The pebble bands varied from a few inches to 4 or 5 feet in thickness, and in my notebook is an entry "exactly like our Bunter." However, we shall return to that later. I only wish at present to record the impression made on me at the time.

What becomes of the water? - The water flowing over the sand may be disposed of in three ways. (1) It may percolate under the surface ; (2) it may be evaporated; (3) it may lodge in pools or lakes in places which are below the general level of the country.

(1) Percolation.- It has been known for a long time that under the dry baked sands of the desert there commonly exists a great store of water, which only needs to be tapped in order to be available for use. In the Sahara artesian wells were sunk by the Greeks and Romans. In Algeria a class of men called Meallem were formerly employed as water-finders, and another class-the $R$ 'tassin-were engaged in the construction and cleaning out of wells. Their methods were primitire and involved great dangers. Since the French occupation more scientific appliances have been introduced, and the fringe of fertile soil on the margin of the great Sahara is gradually being extended southwards. In sinking the dry sand is penetrated until an impermeable clay or pan is reached. On piercing this the water rises. sometimes with sufficient force to reach the surface. The depth of the impermeable layer varies from a few feet to hundreds of feet, and striking differences of level may be encountered within a short distance.

The condition of the water below the impervious bands must necessarily be largely a matter of inference. We naturally want to know whether it is stagnant or flowing, and whether it is carrying substances in solution and depositing these round the sand grains and thus cementing them into compact rock. If the water is flowing it must trend towards an outflow, and if this is restricted in area there must be definite lines along which the water runs. The stream lines will, under these circumstances, be convergent towards the outfall, and the water outside the cone of flowing water may be stagnant.

That subterranean streams of fresh water do flow into the Red Sea from the desert is certain, and opposite their mouths the coral growth round the coast is interrupted. Some of these streams have been traced underground for great distances almost to the base of the 
Abyssinian mountains. The wells in the oases, too, must be fed from the same source.

Similar lines of flow of percolating water can be traced in our local Triassic rocks. Sometimes they show themselves by a deeper staining, and in extreme cases the grains of sand have become so heavily charged with interstitial matter that they have formed pipes, the interior of which is dark brown or eren black, while the sand surrounding is almost white.

(2) Evaporation.-Another way in which the water flowing from the high grounds is disposed of is by evaporation. The amount of evaporation is largely dependent on the relative humidity of the air. Over the oceans the air may be approximately saturated, but in deserts the amount is commonly as low as 20 per cent. of the total capacity of the air to hold moisture. At Assuan it is 38 per cent. for the year, varving from 29 per cent. in Summer to 51 per cent. in Winter. At Wadi Halfa the average for the year is 32 per cent.

When the air is not saturated, there is a constant exchange of water from the land to the atmosphere, and this results in evaporation at the surface and a creep of water from below owing to capillary action. Mineral substances contained in solution are disengaged from the water on evaporation at the surface, and the soils in course of time become charged with saline matter. In this way the 'sour' or 'alkaline' soils have their origin.

The nature of the encrustation will, of course, depend on the composition and the amount of salts which the water holds in solution, and these again are dependent on the nature of the rocks over which the water passes. Potash and soda salts are common encrustations in some regions, and they are often associated with the carbonates and sulphates of the alkaline earths. The former may be redissolved and partly removed in the rainy season, but the salts of the alkaline earths will be effected only to a very slight extent and will tend to accumulate. A very instructive example of this occurs in the dry donga near Vryheid mentioned above. Near the surface the sands are coated with carbonate of lime. Sometimes there appear embedded in the sand roundish balls, ranging from the size of a marble to that of a man's head. In other places limestone of a compact texture and not enclosing sand forms a continuous layer on the surface of the ground.

At Croft, near Leicester, a calcareous crust exactly resembling that found in deserts occurs on the surface of the underlying igneous rock, and the covering Keuper marls are strongly impregnated with lime salts.

(3) Desert Pools and Lakes. - Looking across a vast expanse of desert the monotony of the scene tends to dwarf the sense of vertical height. With no outstanding features to rivet the attention of the eye the rolling dunes or naked rock give the impression of a level landscape. As a matter of fact the desert has its hills and its hollows, its crags and its ravines. In some of these hollows, enclosed in a network of dunes or in rocky basins, water tends to accumulate and form pools or lakes. They may be fed by rain, by water percolating through the surface sand, or by streams flowing from the hills. 
Often they have no outlet, and then the water can only be lost by evaporation. They are full to overflowing when the seasonal rains fall, but during the long drought the waters gradually diminish, and in many instances totally disappear.

The water which finds its way into these pools or lakes brings with it matter in suspension and in solution. The former settles at the bottom as a fine mud. The mud, on drying, shrinks and forms the triradiate cracks characteristic of contracting sheets; it receives the imprints of animals' feet when they come to drink, and the impressions of rain when it falls.

The mud from the margin of a partially dried up vley at Riverton in South Africa shows all these features, and in addition it contains vast quantities of the carapaces of Estheria, a tiny Crustacean which has its proper habitat in such surroundings. ${ }^{1}$

The matter brought into the pools in solution will tend to concentrate as the water diminishes, and on complete drying, deposits of salt, gypsum and other salts will be left behind.

The salinity of the water will vary with the season. Thus, pools in the Rajputana desert in India are fresh for two or three months in the year. One constantly comes across contradictory statements in reading books of travel as to the salinity or otherwise of certain lakes. The observations may be right in each case if the travellers visited the lakes at different seasons of the year.

(To be concluded in our next $N$ tumber.)

\section{凡円マエ円W}

\section{Memorrs of the Geological Survey.}

I.-The Geology of the Socth Wales Coalfield. Part VII: The Country around Ammanford. By Dr. A. Strahan, F.R.S., T. C. Cantrill, B.Sc., E. E. L. Dixon, B.Sc., and H. H. Thomas, B.Sc. Text, pp. 246, with 12 illustrations, price $2 s .6 d$. Colourprinted maps, Sheet 230, Drift and Solid, 18.6 $d$. each.

Part VIII: The Country around Swansea. By Dr. A. Strahan, with parts by R. H. Trddeman, M.A., Dr. W. Gibson, and E. E. L. Drxon, B.Sc. Text, pp. 170, with 4 illustrations and 5 plates, price 2s. 6d. Colour-printed maps, Sheet 247, Drift and Solid, $1 s .6 d$. each.

$\mathrm{W}$

ITH the publication of these Memoirs and that of Part IX (West Gower) already noticed in the Geological Magazine (August, 1907, p. 371) we witness the completion of the surrey of the main portions of the great South Wales Coalfield, and Dr. Strahan is to be congratulated on the progress thus made in a task in which he has taken the prominent part and has personally superintended.

1 "Habitat of Estheria" : Trias Report, British Association, 1905; and Monog. Pal. Soc., 1862, p. 57. 